\title{
Hormonal and metabolic effects of genistein and daidzein in male rat*
}

\author{
K. Szkudelska ${ }^{1}$, L. Nogowski, P. Kaczmarek, E. Pruszyńska-Oszmałek, \\ R. Szkudelski, A. Sieczka and T. Szkudelski
}

\author{
August Cieszkowski Agricultural University, \\ Department of Animal Physiology and Biochemistry \\ 60-637 Wotyńska 35, Poznań, Poland
}

(Received 20 May 2003; revised version 15 July 2003; accepted 28 October 2003)

\begin{abstract}
Genistein and daidzein belong to a large group of compounds called phytooestrogens present in several plants consumed by animals. Apart from oestrogenic activity, these compounds influence on many different processes in the organism. Their effect on metabolic processes was previously observed, however, it is poorly understood. In the performed experiment the effect of genistein $(5 \mathrm{mg} / \mathrm{kg}$ $\mathrm{BW})$ or daidzein $(5 \mathrm{mg} / \mathrm{kg} \mathrm{BW})$ administered intragastrically for three days to growing male rats was studied and compared to oestradiol $(0.1 \mathrm{mg} / \mathrm{kg} \mathrm{BW})$. Both phytooestrogens and oestradiol caused slight increase in blood glucose content with concomitant drop in insulin level. Blood cholesterol and HDL-cholesterol were not statistically altered. However, a slight reduction in total cholesterol with simultaneous slight rise in HDL-cholesterol in rats receiving oestradiol and phytooestrogens caused that HDL-cholesterol/total cholesterol ratio was significantly higher in these animals. The tested substances had no influence on blood free fatty acids and triglycerides. All these compounds caused substantial diminution in muscle triglycerides content. Liver glycogen, triglycerides and cholesterol contents were augmented only by daidzein.

Our results indicate that genistein and daidzein evoked many similar metabolic changes. These changes were comparable to those caused by oestradiol and to changes induced by genistein and observed previously in ovariectomized rats.
\end{abstract}

KEY WORDS: genistein, daidzein, metabolism, rats

\footnotetext{
* Supported by the Scientific Committee for Scientific Research, Grant No. 3 PO6D 00223

K. Szkudelska has a fellowship of The Foundation for Polish Science

${ }^{1}$ Corresponding author: e-mail: tszkudel@jay.au.poznan.pl
} 


\section{INTRODUCTION}

Phytooestrogens are naturally occurring diphenolic compounds widely present in vegetables, fruits and whole grains commonly consumed by animals and humans. The number of such classes of compounds is identified as having biological activity. Genistein and daidzein belong to the class of isoflavones. They are the major bioactive isoflavones, which are derived from their plant precursors biochanin A and formononetin, respectively, and exist in plants either as the bioactive aglycones (genistein and daidzein) or in the inactive form as glycosides - genistin and daidzin (reviewed by Tham et al., 1998). In plant kingdom, soya is the richest source of isoflavones - it contains milligrams of these compounds per gram dry matter but isoflavones occur also in clover, legumes, toothed medic and bluegrass (Price and Fenwick, 1985).

Isoflavones undergo partial metabolism by intestinal microflora in the gastrointestinal tract and both metabolites and parent compounds, bioactive aglycones, are absorbed (Tham et al., 1998). Genistein appears in plasma after consumption of soya extract as well as after administration of the single dose of pure phytooestrogen. In was demonstrated that in rats plasma genistein concentration at $2 \mathrm{~h}$ after its administration was $11 \pm 2.3 \mu \mathrm{M}$ in the genistein-treated rats compared to $4.9 \pm 0.2$ $\mu \mathrm{M}$ in the soya extract-treated animals, but there were no significant differences at $8 \mathrm{~h}$ and later (King et al., 1996).

Like endogenous oestrogens, genistein, daidzein and their metabolites are excreted in both urine and bile and the urinary recoveries may reach about $20 \%$ of consumption (King et al., 1996).

Isoflavones as phytooestrogens demonstrate oestrogenic activity. This activity was first recognized in sheep and is known as so called clover disease (Bennetts et al., 1946). The consumption of clover caused reproductive disorder or even permanent infertility. It was found that this effect was evoked by genistein, daidzein and their precursors in clover (Shutt and Cox, 1972). In cheetah population isoflavones present in the diet had also a major role in the decline of fertility (Setchell et al., 1987). In female Wistar rats administration of soya diet induced changes in the uterine: increase in uterine weight, oedema, endothelial hyperplasia and leucocytic infiltration. There were also observed vaginal modifications such as inflammation, hyperkeratosis and dyskeratosis (Gallo et al., 1999).

In view of the current data, isoflavones have been accepted to posses a beneficial rather than deleterious effects. Genistein has an important antioxidant properties. In Sprague-Dawley rats it profoundly decreased all parameters of lipoprotein oxidation (Anderson et al., 1998). There were also observed antitumor effects of isoflavones in animals. The consumption of isoflanone-rich soya-based diet has been shown to protect rodents from experimentally induced cancers of the mammary gland and colon (Lamartiniere et al., 1995; Thiagarajan et al., 1998). 
The literature data indicate that these compounds have also an inhibitory role in the proliferation of cultured cancer cells and in various stages of tumor development.

Recently, a great deal of interest has been directed toward the findings that isoflavones have a beneficial role in obesity and diabetes mellitus. The consumption of isoflavones, genistein and daidzein was associated with lower body mass indexes and fasting insulin concentrations (reviewed by Bhathena and Velasquez, 2002). In our previous experiments the substantial effect of genistein and daidzein on metabolism of adipocytes was also demonstrated (Nogowski et al., 1998; Szkudelska et al., 2000, 2002). Metabolic changes in adipocytes may be evoked by several dietary factors (Kandulska and Szkudelski, 1998) and may influence the whole body metabolism.

Many experiments conducted in order to test metabolic effects of phytooestrogens was performed on females. Ovariectomized animals were used to avoid the influence of endogenous oestrogens (Maćkowiak et al., 1999; Nogowski et al., 2002). However, tissues of males are also abundant in oestrogen receptors. Besides, some effects of phytooestrogens are independent on their interaction with oestrogen receptors (Wang and Kurzer, 1997; Szkudelska et al., 2000). Therefore, it is possible that food-derived phytooestrogens may affect also males.

The purpose of this experiment was to test the influence of short-time genistein and daidzein administration on blood insulin and glucagon concentrations and some metabolic parameters in male rats. The effects of phytooestrogens were compared with oestradiol which is able to induce hormonal and metabolic changes already in short-time after treatment.

\section{MATERIAL AND METHODS}

Male Wistar rats weighing $190 \pm 10 \mathrm{~g}$ were used in the experiment. Animals were kept at constant temperature $\left(21 \pm 1^{\circ} \mathrm{C}\right)$ with a 12-h dark-light cycle in air conditioned animal room and fed ad libitum a complete standard laboratory diet (Labofeed B, Poland) containing (\%): crude protein 17, crude fat 3.5, crude fibre 7 and net energy $12.15 \mathrm{MJ} / \mathrm{kg}$. Rats were divided into four groups of seven animals each: control, 17 $\beta$-oestradiol-, genistein- and daidzein-treated. Oestradiol and phytooestrogens (derived from Sigma) were dissolved in dimethylsulphoxid (DMSO, Merck) : water mixture $3: 7$ and were given intragastrically $(0.5 \mathrm{ml} / 100$ $\mathrm{g} \mathrm{BW}$ ) for 3 days as a single dose, at the same hour every day. Oestradiol was given in the amount $0.1 \mathrm{mg} / \mathrm{kg} \mathrm{BW}$, genistein $5 \mathrm{mg} / \mathrm{kg} \mathrm{BW}$ and daidzein $5 \mathrm{mg} / \mathrm{kg}$ BW. Concentrations of compounds in given fluid were: $73.4 \mu \mathrm{M}$ for oestradiol, $3.7 \mathrm{mM}$ for genistein and $3.9 \mathrm{mM}$ for daidzein. Control animals received the same amount of vehicle. Animals were decapitated about $18 \mathrm{~h}$ after the last treat- 
ment, between 8 and 10 a.m. and their blood serum, livers and thigh muscles ( $M$. biceps femoris) were collected and stored $\left(-80^{\circ} \mathrm{C}\right)$ until analysis. Serum insulin and glucagon were assayed radioimmunologically using kits specific for rat hormones (Linco Research Inc., USA). Glucose was determined enzymatically using o-dianisidin, peroxidase and glucose oxidase (Sigma). Free fatty acids were assayed by the method of Duncobe (1964). The serum cholesterol was determined by the enzymatic method of Richmond (1973). HDL-cholesterol was assayed as in serum after separation of high density lipoproteins using polyethylene glycol (PEG 6000). Triglycerides were determined according to Foster and Dunn (1973). To determine tissue glycogen content, samples of liver and muscle were hydrolysed in $30 \% \mathrm{KOH}$. Then glycogen was extracted and hydrolysed with amyloglucosidase ( $12 \mathrm{U} / \mathrm{ml}$ in $0.2 \mathrm{M}$ acetate buffer, $\mathrm{pH} 4.5$, at $55^{\circ} \mathrm{C}$, for $90 \mathrm{~min}$ ) and determined as glucose. Liver and muscle triglycerides and liver cholesterol were determined similarly as in serum after extraction of total lipids using the method of Folch et al. (1975). The obtained extracts were evaporated before use for cholesterol determination.

Results obtained in the experiment were evaluated statistically using one-way analysis of variance (ANOVA) and a Duncan's multiple range test.

The experiment was performed according to rules accepted by Local Ethical Commission for Investigation on Animals.

\section{RESULTS}

Oestradiol, genistein and daidzein given to growing rats had no influence on body weight gain (Table 1). However, some metabolic parameters were changed by these compounds as early as after three days of their administration (Table 1). Oestradiol and both phytooestrogens caused slight rise in blood glucose concentration. This effect of phytooestrogens was accompanied by simultaneous diminution in insulin concentration. Glucose/insulin ratio was significantly augmented in animals treated with phytooestrogens. In the case of oestradiol this effect was less marked. In all rats treated with oestradiol or phytooestrogens serum glucagon was tended to be increased, however, the increase was not statistically significant. Genistein and daidzein caused substantial rise in insulin/glucagon molar ratio. Oestradiol evoked similar tendency, but this effect was weaker. Blood contents of triglycerides and free fatty acids were not affected. Total, esterified and free cholesterol and HDL-cholesterol were not significantly changed as a result of oestradiol or phytooestrogens administration. However, the amount of cholesterol in high density lipoproteins (HDL) tended to be increased in rats treated with oestradiol, genistein or daidzein. The HDL-cholesterol/total cholesterol ratio was significantly augmented by oestradiol and phytooestrogens. Daidzein 
TABLE 1

The influence of oestradiol, genistein and daidzein on body weight gain, insulin, glucagon and some metabolic parameters in male rats

\begin{tabular}{|c|c|c|c|c|}
\hline Parameter & Vehicle & Oestradiol & Genistein & Daidzein \\
\hline Body weight gain, g/day & $6.6 \pm 0.7$ & $5.5 \pm 0.6$ & $5.8 \pm 0.7$ & $6.4 \pm 0.8$ \\
\hline Glucose, $\mathrm{mmol} / \mathrm{l}$ & $4.788 \pm 0.102^{\mathrm{A}}$ & $5.371 \pm 0.182^{b}$ & $5.208 \pm 0.171^{\mathrm{b}}$ & $5.784 \pm 0.132^{\mathrm{B}}$ \\
\hline Insulin, ng/ml & $3.337 \pm 0.250^{\mathrm{A}}$ & $3.130 \pm 0.192^{\mathrm{A}}$ & $1.813 \pm 0.276^{\mathrm{B}}$ & $2.442 \pm 0.124^{\mathrm{B}}$ \\
\hline Glucose/insulin ratio & $1.435 \pm 0.128^{\mathrm{A}}$ & $1.716 \pm 0.261^{\mathrm{a}, \mathrm{c}}$ & $2.872 \pm 0.489^{\mathrm{B}}$ & $2.368 \pm 0.208^{\mathrm{B}, \mathrm{c}}$ \\
\hline Glucagon, $\mathrm{pg} / \mathrm{ml}$ & $114 \pm 6.427$ & $120 \pm 5.647$ & $121 \pm 10.422$ & $123 \pm 10.368$ \\
\hline Insulin/glucagon molar ratio & $19.470 \pm 1.321^{\mathrm{A}}$ & $17.502 \pm 2.643$ & $10.404 \pm 1.793^{\mathrm{B}}$ & $16.281 \pm 1.666^{\mathrm{c}}$ \\
\hline Free fatty acids, mmol/1 & $0.397 \pm 0.009$ & $0.365 \pm 0.003$ & $0.378 \pm 0.011$ & $0.326 \pm 0.007$ \\
\hline Triglycerides, mmol/1 & $2.741 \pm 0.065$ & $2.952 \pm 0.159$ & $2.479 \pm 0.110$ & $2.772 \pm 0.077$ \\
\hline \multicolumn{5}{|l|}{ Cholesterol, mmol/1 } \\
\hline total & $1.524 \pm 0.105$ & $1.347 \pm 0.124$ & $1.491 \pm 0.104$ & $1.442 \pm 0.077$ \\
\hline esterified & $1.109 \pm 0.086$ & $0.967 \pm 0.095$ & $1.110 \pm 0.076$ & $1.045 \pm 0.051$ \\
\hline free & $0.415 \pm 0.027$ & $0.380 \pm 0.036$ & $0.381 \pm 0.034$ & $0.396 \pm 0.032$ \\
\hline \multicolumn{5}{|l|}{ HDL cholesterol } \\
\hline $\mathrm{mmol} / 1$ & $0.424 \pm 0.023$ & $0.434 \pm 0.029$ & $0.469 \pm 0.026$ & $0.493 \pm 0.027$ \\
\hline \multicolumn{5}{|l|}{ Cholesterol } \\
\hline HDL/total, mmol/l & $0.281 \pm 0.012^{\mathrm{A}}$ & $0.330 \pm 0.019^{\mathrm{b}}$ & $0.317 \pm 0.012^{\mathrm{b}}$ & $0.342 \pm 0.006^{\mathrm{B}}$ \\
\hline Liver glycogen, $\mathrm{g} / \mathrm{kg}$ & $58.561 \pm 3.508^{\mathrm{A}}$ & $66.263 \pm 4.501$ & $59.307 \pm 2.503$ & $72.52 \pm 2.492^{\mathrm{B}}$ \\
\hline Liver triglycerides, $\mathrm{mmol} / \mathrm{kg}$ & $21.687 \pm 1.299^{\mathrm{a}}$ & $22.146 \pm 1.406$ & $21.914 \pm 1.177$ & $27.055 \pm 1.983^{b}$ \\
\hline Liver cholesterol, $\mathrm{mmol} / \mathrm{kg}$ & $3.118 \pm 0.291^{\mathrm{A}}$ & $2.920 \pm 0.150$ & $3.533 \pm 0.245$ & $3.842 \pm 0.166^{\mathrm{B}}$ \\
\hline Muscle glycogen, $\mathrm{g} / \mathrm{kg}$ & $4.608 \pm 0.216$ & $4.095 \pm 0.311$ & $4.446 \pm 0.339$ & $5.135 \pm 0.586$ \\
\hline $\begin{array}{l}\text { Muscle triglycerides } \\
\mathrm{mmol} / \mathrm{kg}\end{array}$ & $24.374 \pm 3.273^{\mathrm{A}}$ & $12.470 \pm 1.565^{\mathrm{B}}$ & $9.457 \pm 0.849^{\mathrm{B}}$ & $10.878 \pm 1.921^{\mathrm{B}}$ \\
\hline
\end{tabular}

$17 \beta$-oestradiol $(0.1 \mathrm{mg} / \mathrm{kg} \mathrm{BW})$, genistein $(5 \mathrm{mg} / \mathrm{kg} \mathrm{BW})$ and daidzein $(5 \mathrm{mg} / \mathrm{kg} \mathrm{BW})$ were dissolved in DMSO : $\mathrm{H}_{2} \mathrm{O}(3: 7 ; 0.5 \mathrm{ml} / 100 \mathrm{~g} \mathrm{BW})$ and were administered intragastrically once a day for 3 days. Values are means \pm SEM for seven rats. Means in the same row with different letter superscripts are significantly different $\left({ }^{\mathrm{a}, \mathrm{b}}-\mathrm{P} \leq 0.05,{ }^{\mathrm{A}, \mathrm{B}}-\mathrm{P} \leq 0.01\right)$.

increased liver glycogen, triglycerides and cholesterol contents. This effect was not observed in the case of oestradiol and genistein. The influence of the tested compounds on muscle triglycerides was similar - in rats treated with all these compounds a sudden drop in muscle triglycerides was found. Muscle glycogen content was not significantly changed.

\section{DISCUSSION}

One of the effects of oestradiol action, observed also in our experiment (Table 1), is its influence on glucose homeostasis. Its action may be contradictory depending on the hormone concentration. Low doses of oestradiol stimulate insulin secretion and improve its action whereas high doses inhibit insulin secretion and deteriorate 
its action (González et al., 2002). In our experiment rats treated for three days with oestradiol manifested a slight increase in blood glucose concentration. This effect was, however, not accompanied by any rise in blood insulin content. Similar alterations in blood glucose with concomitant drop in blood insulin were observed in rats treated with genistein and daidzein. Changes evoked by these phytooestrogens were, however, more profound compared to oestradiol. Under physiological conditions the rise in blood glucose causes immediate increase in insulin secretion and the concentration of this hormone in blood is also elevated to diminish blood glucose level. In our experiments this was not the case and in rats treated with genistein and daidzein blood insulin was diminished in spite of increased glucose level. Similar changes in blood glucose and insulin were found in ovariectomized rats fed for two weeks a diet enriched in genistein (Nogowski et al., 1998). These results may suggest the direct inhibitory action of the tested compounds on insulin secretion. Such as effect is well known for oestradiol (Etchegoyen et al., 1998; own unpublished results) but data concerning the influence of genistein and daidzein on insulin secretion in the rat are lacking. Apart from diminution in insulin secretion, the deterioration in insulin action on target tissues by tested compounds was also taken into consideration. Impairment in insulin sensitivity in animals is characteristic for high doses of oestradiol (González et al., 2002). Genistein was also found to decrease insulin receptor number and insulin binding to its receptor (Maćkowiak et al., 1999; Nogowski et al., 2002). In our experiment the glucose/insulin ratio was augmented in rats treated with oestradiol and phytooestrogens. However, this effect resulted from a simultaneous rise in blood glucose and a drop in blood insulin and does not suggest that insulin action was impaired.

Neither oestradiol nor phytooestrogens affected serum free fatty acids and triglycerides. In other experiments performed on ovariectomized rats these metabolic parameters were influenced by oestradiol and genistein, but after longer period of time (Nogowski et al., 1998).

In rats receiving oestradiol and phytooestrogens serum cholesterol was not significantly altered whereas HDL-cholesterol tended to be increased. Besides, oestradiol and both phytooestrogens evoked significant rise in HDL-cholesterol/total cholesterol ratio. The rise in this ratio favours elimination of cholesterol from the blood via its transport to the liver and excretion in the bile. Such an effect is considered as antiatherogenic and was previously observed for oestradiol (Alvarez et al., 2002). This hormone may influence not only cholesterol elimination but also its metabolism. These effects depends, however, on its concentration (Parini et al., 2000). The literature data provide evidence that consumption of diets containing soya protein (and phytooestrogens which are tightly associated with proteins) reduces total cholesterol and LDL-cholesterol (Carroll, 1991) and augments HDL-cholesterol (Anthony et al., 1996). However, it is not clear whether these beneficial effects are evoked by soya protein, phytooestrogens or other compounds (Kurzer and $\mathrm{Xu}$, 
1997). Our results indicate that pure phytooestrogens - genistein and daidzein - are responsible, at least in part, for antiatherogenic effect of soya containing diets. This observation, of course, does not exclude that other compounds of vegetable diets may have also similar beneficial influence on blood cholesterol.

Among tested compounds, only daidzein significantly augmented liver glycogen, triglycerides and cholesterol content. Because other metabolic changes and blood hormone concentrations were similar in the case of daidzein, genistein and oestradiol, this effect of daidzein seems to result from its direct influence on the liver. These effects indicate that daidzein exerts metabolic changes favouring anabolic processes in the liver tissue.

Muscle triglycerides content was substantially reduced by oestradiol and both phytooestrogens. Similar effect was previously observed in ovariectomized rats consuming a diet enriched in genistein (Nogowski et al., 1998). Besides, our previous experiments revealed that genistein (Szkudelska et al., 2000), daidzein and oestradiol (Szkudelska et al., 2002) restricted glucose conversion to triglycerides in isolated rat adipocytes. Several aspects of glucose transport and metabolism are similar in adipocytes and muscles. Therefore, the inhibitory effect of these phytooestrogens on synthesis of triglycerides found in adipocytes is possible also in muscles.

Results obtained in our experiment clearly indicate that genistein and daidzein significantly affect blood insulin concentration and some metabolic parameters in male rats. Genistein was previously reported to exert an influence on carbohydrate and lipid metabolism in ovariectomized rats, however, in the case of daidzein this is the first study demonstrating its metabolic activity. Changes evoked by genistein and daidzein were observed already after three days of their administration and were similar to alterations found after longer period of time in ovariectomized rats consuming a diet enriched in phytooestrogens. The observed changes were, at least in great part, similar for both tested phytooestrogens and were also comparable to those evoked by oestradiol. Our results obtained in this experiment and in experiments performed previously prove that some metabolic processes are similarly affected by genistein and daidzein in both females and males. The consequences of the metabolic action of phytooestrogens on performance of livestock animals are, as yet, difficult to define. Further experiments are required to explain these effects.

\section{REFERENCES}

Alvarez A., Hermenegildo C., Issekutz A.C., Esplugues J.V., Sanz M.J., 2002. Estrogens inhibit angiotensin II-induced leukocyte-endothelial cell interactions in vivo via rapid endothelial nitric oxide synthase and cyclooxygenase activation. Circ. Res. 13, 1142-50 
Anderson J.W., Diwadkar V.A., Bridges S.R., 1998. Selective effects of different antioxidants on oxidation of lipoproteins from rats. Proc. Soc. Biol. Med. 218, 376-381

Anthony M.S., Clarkson T.B., Hughes C.L. Jr., Morgan T.M., Burke G.L., 1996. Soybean isoflavones improve cardiovascular risk factors without affecting the reproductive system of peripubertal rhesus monkeys. J. Nutr. 126, 43-50

Bennetts H.W., Underwood E.J., Shier F.L., 1946. A specific breeding problem of sheep on subterranean clover pastures in western Australia. Aust. Vet. J. 22, 2-12

Bhathena S.J., Velasquez M.T., 2002. Beneficial role of dietary phytoestrogens in obesity and diabetes. Amer. J. Clin. Nutr. 76, 1191-1201

Carroll K.K., 1991. Review of clinical studies on cholesterol-lowering response to soy protein. J. Amer. Diet. Assn. 91, 820-827

Duncombe D., 1964. The colorimetric micro-determination of nonesteryfied fatty acids in plasma. Clin. Chim. Acta 9, 122-125

Etchegoyen G.S., Borelli M.I., Rossi J.P., Gagliardino J.J., 1998. Effect of 2-hydroxyestradiol on insulin secretion in normal rat pancreatic islets. Diabetes Metab. 24, 428-433

Folch J., Lees M., Sloane G.S.H., 1975. A simple method of the isolation and purification of total lipids from animal tissues. J. Biol. Chem. 226, 497-509

Foster L.B., Dunn R.T., 1973. Stable reagents for determination of serum triglicerides by colorimetric Hatzsh condensation method. Clin. Chem. 19, 338-340

Gallo D., Cantalemo F., Distefano M., Ferlini C., Zannini G.F., Riva A., Morazzoni P., Bombardelli E., Mancuso S., Scambia G., 1999. Reproductive effects of dietary soy in female Wistar rats. Food Chem. Toxicol. 37, 493-502

Gonzalez C., Alonso A., Grueso N.A., Diaz F., Esteban M.M., Fernandez S., Patterson A.M., 2002. Role of $17 \beta$-estradiol administration on insulin sensitivity in the rat: implications for the insulin receptor. Steroids 67, 993-1005

Kandulska K., Szkudelski T., 1998. The effect of diet on fat cell metabolism. A review. J. Anim. Feed Sci. 7, 233-248

King R.A., Broadbent J.L., Head R.J., 1996. Absorption and excretion of the soy isoflavone genistein in rats. J. Nutr. 126, 176-182

Kurzer M.S., Xu X., 1997. Dietary phytoestrogens. Annu. Rev. Nutr. 17, 353-381

Lamartiniere C.A., Moore J.B., Brown N.M., Thompson R., Hardin M.J., Barnes S., 1995. Genistein suppresses mammary cancer in rats. Carcinogenesis 16, 2833-2840

Maćkowiak P., Nogowski L., Nowak K.W., 1999. Effect of isoflavone genistein on insulin receptors in perfused liver of ovariectomized rats. J. Recept. Signal. Transduct. Res. 19, 283-292

Nogowski L., Maćkowiak P., Kandulska K., Szkudelski T., Nowak K.W., 1998. Genistein-induced changes in lipid metabolism of ovariectomized rats. Ann. Nutr. Metab. 42, 360-366

Nogowski L., Nowak K.W., Kaczmarek P., Maćkowiak P., 2002. The influence of coumestrol, zearalenone, and genistein administration on insulin receptors and insulin secretion in ovariectomized rats. J. Recept. Signal Transduct. Res. 22, 449-457

Parini P., Angelin B., Stavreus-Evers A., Freyschuss B., Eriksson H., Rudling M., 2000. Biphasic effects of the natural estrogen $17 \beta$-estradiol on hepatic cholesterol metabolism in intact female rats. Arterioscler. Thromb. Vasc. Biol. 20, 1817-1823

Price K.R., Fenwick G.R., 1985. Naturally occurring oestrogens in foods - a review. Food. Addit. Contam. 2, 73-106

Richmond W., 1973. Preparation and properties of cholesterol oxidase from Nocardia sp. and application to the enzymatic assay of total cholesterol in serum. Clin. Chem. 19, 1350-1356

Setchell K.D.R., Gosselin S.J., Welsh M.B., Johnston J.O., Balistreri W.F., 1987. Dietary estrogens - a probable cause of infertility and liver disease in captive cheetahs. Gastroenterology 93, 225-233 
Shutt D.A., Cox R.I., 1972. Steroid and phytoestrogen binding to sheep uterine receptors in vitro. Endocrinology 52, 299-310

Szkudelska K., Nogowski L., Szkudelski T., 2000. Genistein affects lipogenesis and lipolysis in isolated rat adipocytes. J. Steroid Biochem. Mol. Biol. 75, 265-271

Szkudelska K., Szkudelski T., Nogowski L., 2002. Daidzein, coumestrol and zearalenone affect lipogenesis and lipolysis in rat adipocytes. Phytomedicine 9, 338-345

Tham D.M., Gardner C., Haskell L., 1998. Potential health benefits of dietary phytoestrogens: a review of the clinical, epidemiological and mechanistic evidence. J. Clin. Endocrinol. Metab. $83,2223-2235$

Thiagarajan D.G., Bennink M.R., Bourquin L.D., Kavas F.A., 1998. Prevention of precancerous colonic lesions in rats by soy flakes, soy flour, genistein, and calcium. Amer. J. Clin. Nutr. 68, 1394-1399

Wang C., Kurzer M.S., 1997. Phytoestrogen concentration determines effects on DNA synthesis in human breast cancer cells. Nutr. Cancer 28, 236-247

\section{STRESZCZENIE}

\section{Hormonalne i metaboliczne efekty działania genisteiny i daidzeiny u samców szczura}

Genisteina i daidzeina należą do dużej grupy związków zwanych fitoestrogenami obecnych w wielu roślinach pastewnych. Oprócz aktywności estrogennej, związki te mają wpływ na wiele różnych procesów w organizmie. Wcześniej stwierdzono ich oddziaływanie na procesy metaboliczne, jest ono jednak mało poznane. W przeprowadzonym doświadczeniu badano efekty działania genisteiny $(5 \mathrm{mg} / \mathrm{kg} \mathrm{m}$.c.) i daidzeiny $(5 \mathrm{mg} / \mathrm{kg} \mathrm{m} . c$.) podawanych dożołądkowo przez trzy dni rosnącym samcom szczura i porównano je $\mathrm{z}$ efektami wywołanymi podawaniem estradiolu $(0,1$ $\mathrm{mg} / \mathrm{kg}$ m.c.). Oba fitoestrogeny oraz estradiol spowodowały niewielki wzrost stężenia glukozy we krwi i jednocześnie obniżyły stężenie insuliny. Nie wykazano statystycznie istotnych zmian w zawartości cholesterolu we krwi i we frakcji HDL. Jednak łagodne obniżenie stężenia cholesterolu całkowitego i jednoczesne łagodne zwiększenie zawartości cholesterolu we frakcji HDL u szczurów otrzymujących estradiol i fitoestrogeny spowodowało istotny wzrost stosunku cholesterolu HDL do cholesterolu całkowitego u tych zwierząt. Badane substancje nie miały wpływu na zawartość wolnych kwasów tłuszczowych i triglicerydów we krwi. Wszystkie związki spowodowały istotne $(\mathrm{P} \leq 0.05)$ zmniejszenie zawartości triglicerydów w mięśniach. Daidzeina zwiększyła ilość glikogenu, triglicerydów i cholestereolu w wątrobie.

Otrzymane wyniki wskazują, że genisteina i daidzeina wywołują wiele podobnych zmian metabolicznych. Zmiany te były porównywalne ze zmianami wywołanymi przez estradiol oraz zmianami powodowanymi przez genisteinę, obserwowanymi wcześniej u szczurów owariektomizowanych. 